\title{
Productive performance and carcass characteristics of lambs fed diets containing different levels of palm kernel cake
}

\section{Rendimiento productivo y características de la canal de corderos alimentados con dietas con diferentes niveles de torta de palma}

\author{
Felicidade Macome, ${ }^{1 *}$ M.Sc, Ronaldo Lopes $\mathrm{O},{ }^{2} \mathrm{Ph} . \mathrm{D}$, Adriana Regina $\mathrm{B},{ }^{3} \mathrm{Ph} . \mathrm{D}$, Gherman \\ Garcia Leal A, ${ }^{4}$ Ph.D, Larissa Pires B, ${ }^{3}$ Ph.D, Mauricio Costa Alves Da S, ${ }^{5}$ Ph.D.
}

\begin{abstract}
${ }^{1}$ Agriculture Research Institute of Mozambique. ${ }^{2}$ Departament of animal production. Federal University of Bahia. ${ }^{3}$ Federal University of Bahia Reconcavo. ${ }^{4}$ Embrapa Semi-arid. ${ }^{5}$ Federal University of Bahia. *Correspondence. fmmacome@yahoo.com.br
\end{abstract}

Recibido: Octubre de 2010; Aceptado: Junio de 2011.

\begin{abstract}
Objective. The objective of this study was to determine the effect on productive performance and carcass characteristics in lambs fed with different amounts of palm kernel cake. Material and methods. Thirty-two Santa Inês lambs, with an initial live body weight of $24.8 \pm 3.59 \mathrm{~kg}$ were used. Treatments consisted of four levels $(0 ; 6.5$; 13.0 and $19.5 \%$ ) of palm kernel cake added to the dry matter diet. Lambs were fed for 80 days, and then slaughtered to be evaluated for the quantitative characteristics of the carcass. Results. Intake of dry matter and non-structural carbohydrates decreased with increasing levels of palm kernel cake. The intake of neutral detergent fiber showed a linear increase. Crude protein and total digestive nutrient intake were not affected. Weight gain, and the feed:gain ratio of dry matter, organic matter, crude protein and total digestive nutrients were similar among the four treatments. There was an increase on the feed:gain ratio of neutral detergent fiber and a decrease of nonstructural carbohydrates. The weight gain at slaughter and biometric measures were not affected by treatment. The carcass compactness index showed a linear decrease. The indexes of leg muscularity, compactness of the leg and rib eye area were similar among treatments. There was a linear decrease in the cold carcass weight and commercial yield of the carcass. Conclusions. The diet made of up to $19.5 \%$ palm kernel cake reduced DM intake, the carcass compactness index and carcass commercial yield, but did not alter weight gain, or feed dry matter intake.
\end{abstract}

Key words: Carcasses, diet, feed conversion, palm kernel cake (Source: $C A B$ ). 


\section{RESUMEN}

Objetivo. Determinar el nivel óptimo del torta de palma en la dieta a través del rendimiento y características del canal. Materiales y métodos. Se utilizaron 32 corderos de raza Santa Inés, con peso medio de $24.8 \pm 3.59 \mathrm{~kg}$. Los tratamientos consistieron en cuatro niveles $(0 ; 6.5 ; 13.0$ y $19.5 \%)$ del torta de palma en la materia seca de la dieta. Después de 80 días, los animales fueron sacrificados para la evaluación de las características cuantitativas del canal. Resultados. La ingesta de materia seca y carbohidratos no estructúrales, siguieron comportamiento lineal decreciente. El consumo de la fibra en detergente neutro se incrementó de forma lineal. Los consumos de proteína cruda y nutrientes digestibles totales no fueron afectados. El aumento de peso, el índice de conversión de materia seca, proteína bruta y nutrientes digestibles totales fueron similares. Hubo efecto lineal creciente sobre la conversión alimenticia de la fibra en detergente neutro y lineal decreciente sobre la conversión de carbohidratos no estructurales. Las medidas biométricas no fueron influenciadas. El índice de compacidad de la canal siguió comportamiento linear decreciente, índices de musculatura de la pierna, de compacidad de la pierna y el área de los ojos- del-lombo fueron similares. Hubo efecto lineal decreciente para el peso del canal fria, rendimiento comercial de la canal. Conclusiones. La inclusión del la torta de palma hasta $19.5 \%$ reduce el consumo de la materia seca, índice de compacidad de la canal. La ganancia del peso y la conversión alimentar de la matéria seca fueron semejantes.

Palabras clave: Canal animal, conversión en alimento, dieta, torta de palmiche. (Fuente: CAB).

\section{INTRODUCTION}

Sheep husbandry in the northeast of Brazil has huge socio-economic importance and is focused primarily on meat production (1). There are about 15 million ovine in Brazil, of which $58 \%$ are concentrated in the northeast of the country (2). The herd is composed mainly of undefined breeds, followed by Santa Inês, Morada Nova and Somalis Brasileira breeds (3). There is an increasing demand for qualitative characteristics in lamb meat, such as low levels of fat, according to consumer preferences.

Live body weight is the most important aspect in the market. However, for better interaction between producers and consumers, it is essential to have information on the percentage of cuts and other parts related to the weight of the animals and the quality of the product (4).

The best carcass is one that has the maximum proportion of muscles and bones and the minimum proportion of fat, according to consumer preference. However, there should be sufficient fat to ensure that the meat is succulent and can be well-presented and conserved (5).
The costs of energy and protein concentrate diets are increasing, highlighting the need for alternative lower cost, good quality food that will maintain the productivity of livestock herds. In Brazil, there are several by-products that are compatible with traditional systems and can be used efficiently to feed lambs to achieve meat production quality (6-8).

The processing of seeds generates a considerable amount of by-products that need to be evaluated as alternative sources for animal feed (9) and aggregate income for small producers, such as palm, sunflower, peanut and soybean. In Bahia State, palm kernel cake (Elaeisguineensis), which is derived from the milling and extraction of oil to produce biodiesel, is produced in large quantities (10). Therefore, it could be used in animal feed, with the capacity to meet the nutritional requirements of ruminants (11).

The objective of this study was to determine the productive performance and carcass characteristics in lambs using different amounts of palm kernel cake in the diet. 


\section{MATERIAL AND METHODS}

Study site. This study was conducted in the sheepfold of the Veterinary Medical School of Federal University of Bahia, Ondina Campus, Salvador City, Bahia State.

Animals and treatments. Thirty-two Santa Inês non-castrated male lambs, 4 to 6 months old and weighing $24.8 \pm 3.59 \mathrm{~kg}$ were randomly allocated by replicate (8) into 4 palm kernel cake diet groups: group 1: $0.0 \%$, group 2: $6.5 \%$, group 3: $13.0 \%$ and group $4: 19.5 \%$. Animals were vaccinated, housed in individual pens $(1.0 \times 1.0 \mathrm{~m})$ AND weighed at the beginning of the experiment and then every 2 weeks until day 80 . Diets were offered twice daily (9:00 and 16:00 hr) as total mixed ration, with the quantity adjusted to ensure $10 \%$ to $20 \%$ of leftovers. The concentrate contained corn meal, soybean meal, palm kernel cake and mineral premix for specific commercial sheep.

Daily samples of food and leftovers were collected, identified and stored at $-10^{\circ} \mathrm{C}$.

Dry matter (DM), crude protein (CP), ether extract (EE), ash, neutral detergent insoluble nitrogen (NIDN) and acid detergent insoluble nitrogen (ADIN) were determined according to AOAC (12). The contents of neutral detergent fiber corrected for ash and crude protein (NDFap), acid detergent fiber (ADF), hemicellulose, cellulose and lignin were determined according to Van Soest et al (13) and the percentage of nonstructural carbohydrates (NSC) according to the following equation to Sniffen (14):

$\mathrm{NSC}(\% \mathrm{DM})=100-(\% \mathrm{ASH}+\% \mathrm{CP}+\% \mathrm{EE}+$ $\%$ NDFap).

The chemical composition of the ingredients and diets is presented in table 1 and 2 .

On the day 80 of the experiment, animals were fasted for 16 hours, weighed and slaughtered (BWS). Lambs were stunned with an electric shock in the atlas occipital region, and bled through a section of the carotid artery and jugular. The blood was collected in a plastic bag and weighed. The gastrointestinal tract was individually
Table 1. Chemical composition of ingredients of the experimental diets.

\begin{tabular}{|c|c|c|c|c|}
\hline \multirow[b]{2}{*}{ Item } & \multicolumn{4}{|c|}{ Component } \\
\hline & $\begin{array}{l}\text { Maize } \\
\text { meal }\end{array}$ & $\begin{array}{c}\text { Soybean } \\
\text { meal }\end{array}$ & $\begin{array}{c}\text { Palm } \\
\text { kernel } \\
\text { cake }\end{array}$ & $\underset{\text { Hafton-85 }}{\text { Hay }}$ \\
\hline Dry matter (\%) & 88.68 & 89.73 & 95.29 & 93.37 \\
\hline Organic matter $\mathbf{1}$ & 98.97 & 93.57 & 96.67 & 93.34 \\
\hline Ash 1 & 1.03 & 6.43 & 3.33 & 6.66 \\
\hline Crude protein $\mathbf{1}$ & 4.53 & 46.52 & 16.64 & 8.28 \\
\hline ADIN (\% N total) & 6.00 & 2.00 & 20.00 & 16.00 \\
\hline NDIN (\% N total) & 20.00 & 8.00 & 43.00 & 53.00 \\
\hline $\begin{array}{l}\text { Neutral detergent } \\
\text { fibre } \mathbf{1}\end{array}$ & 12.12 & 11.29 & 70.04 & 83.65 \\
\hline $\begin{array}{l}\text { Acid detergent } \\
\text { fibre } \mathbf{1}\end{array}$ & 3.70 & 8.16 & 45.71 & 45,32 \\
\hline Lignin 1 & 1.06 & 0.65 & 15.72 & 13.15 \\
\hline Cellulose $\mathbf{1}$ & 2.64 & 7.51 & 29.99 & 32.17 \\
\hline Hemicellulose ${ }^{1}$ & 8.42 & 3.12 & 24.33 & 38.33 \\
\hline $\begin{array}{l}\text { Non-structural } \\
\text { carbohydrates } \mathbf{1}\end{array}$ & 79.31 & 33.15 & 2.21 & 0.79 \\
\hline Ether extract $\mathbf{1}$ & 3.01 & 2.61 & 7.78 & 0.62 \\
\hline
\end{tabular}

$1 \%$ of dry matter.

weighed; both full and empty, to determine the gastrointestinal content (GIC) and empty body weight (EBW). After removal of the head and members, the hot carcass (HCW) was weighed and the following morphometric characteristics assessed internal carcass length (ICL): distance from the front edge of the pubic bone to the front edge of the first rib on its midpoint; external carcass length (ECL): distance from cervical-thoracic articulation to the first

Table 2. Chemical composition of experimental diets.

\begin{tabular}{|c|c|c|c|c|}
\hline \multirow[t]{2}{*}{ Item } & \multicolumn{4}{|c|}{ Level of palm kernel cake 1} \\
\hline & 0.00 & 6.50 & 13.00 & 19.50 \\
\hline Dry matter $\mathbf{1}$ & 91.34 & 91.70 & 92.12 & 92.56 \\
\hline Organic matter $\mathbf{1}$ & 95.57 & 95.83 & 95.75 & 95.66 \\
\hline Ash 1 & 4.43 & 4.50 & 4.58 & 4.66 \\
\hline Crude protein $\mathbf{1}$ & 11.00 & 11.23 & 11.46 & 11.70 \\
\hline ADIN ( $\% \mathrm{~N}$ total) & 10.46 & 11.39 & 12.36 & 13.36 \\
\hline NDIN (\% N total) & 35.91 & 37.36 & 38.87 & 40.42 \\
\hline Neutral detergent fibre $\mathbf{1}$ & 47.60 & 51.26 & 55.05 & 58.97 \\
\hline Acid detergent fibre ${ }^{1}$ & 24.89 & 27.49 & 30.18 & 32.96 \\
\hline Lignin 1 & 7.52 & 8.40 & 9.30 & 10.23 \\
\hline Cellulose $\mathbf{1}$ & 17.37 & 19.09 & 20.87 & 22.72 \\
\hline Hemicellulose ${ }^{1}$ & 22.71 & 23.77 & 24.87 & 26.01 \\
\hline $\begin{array}{l}\text { Non-structural } \\
\text { carbohydrates } 1\end{array}$ & 35.22 & 30.96 & 26.54 & 21.97 \\
\hline Ether extract $\mathbf{1}$ & 1.72 & 2.03 & 2.34 & 2.67 \\
\hline Total digestible nutrients (\%) & 70.01 & 73.89 & 70.49 & 75.56 \\
\hline
\end{tabular}


intercoccigean articulation; length of the leg (LL): distance from the greater trochanter of the femur to the edge of the tarsalmetatarsal articulation; width of the rump (WR): trochanters between the maximum width of the femur; perimeter of the rump $(P R)$ : in the perimeter region of the hip based on the femurs' trochanters; perimeter of the leg (PP): based on the middle leg, femur, above of the knee articulation; and perimeter of the thorax (PT): contour behind the shoulder, according to the methodology described by Yanez et al (15).

Carcasses were cooled at $4^{\circ} \mathrm{C}$ for 24 hours, and were then weighed to determine the cold carcass weight (CCW). The commercial yield of the carcass was determined by equation $(\mathrm{CYC}=\mathrm{HCW} / \mathrm{EBW} \times 100)$ and the refrigeration yield by $(R Y=H C W \times 100)$. The carcasses were then split longitudinally, at the midline, into two antimers, and the left half-carcass was sectioned into five anatomical regions: leg, loin, ribs, shoulder and neck, following an adaptation of three methodologies (16-18). The carcasses were then cut between the 12 th and 13 th ribs to determine the rib eye area (REA) through appropriate pen on transparent plastic film. The rib eye area was determined by means of a ruler, the maximum width $(A)$ and maximum depth $(B)$ being used in the formula $\operatorname{REA}=(A / 2 * B / 2) \Pi$. The carcass compactness index (cold carcass weight divided by the internal length of the carcass) and compactness of the leg (rump width divided by the length of the leg) were calculated (19).
The legs were wrapped in plastic bags and kept at $-10^{\circ} \mathrm{C}$ for later dissection (20). Before dissection, the legs were thawed at $10^{\circ} \mathrm{C}$ for 20 hours, within the plastic bags, after which any extra tissue (blood vessel, subcutaneous and intermuscular fat) was withdrawn. The femoral biceps muscle, semitendinosus, adductor, semimembranosus and quadriceps femoral were separated and individually weighed. The index of muscularity of the leg was calculated by the formula described by Purchas et al (21): IML $=[($ WM5/LF/LF $]$ 0.5 , where WM5 is the weight in grams $(\mathrm{g})$ of the five muscles that cover the femur (femoral biceps, semitendinosus, adductor, semimembranosus and quadriceps femoral), and $L F$ is the length of the femur in $\mathrm{cm}$.

Data analyses. Data were randomly allocated by replicate (8) and analyzed by one way ANOVA (Analysis of Variance) and regression, using the statistical package SPSS (22).

\section{RESULTS}

DM intake, the consumption of nonstructural carbohydrates decreased $(p<0.05)$ in response to dietary addition of palm kernel cake (Table 3 ).

The consumption of NDF increased $(p<0.05)$ as the proportion of palm kernel cake increased in the diet. TDN intake was not affected by the amount of palm kernel cake in the diet (Table 3).

Table 3. Intake and weight gain of lambs fed diets containing different levels of palm kernel cake.

\begin{tabular}{|c|c|c|c|c|c|c|c|}
\hline \multirow{2}{*}{ Intake ( $\mathrm{Kg} /$ day $)$} & \multicolumn{4}{|c|}{ Level of palm kernel cake (\%DM) } & \multirow{2}{*}{$\operatorname{cv}(\%)$} & \multirow{2}{*}{$\begin{array}{l}\text { Regression } \\
\text { Equation }\end{array}$} & \multirow{2}{*}{$\mathbf{R}^{2}$} \\
\hline & 0.00 & 6.50 & 13.00 & 19.50 & & & \\
\hline Dry matter & 1.33 & 1.17 & 1.28 & 1.12 & 14.25 & $\hat{Y}=1.314-0.09 X$ & 0.512 \\
\hline Non-structural carbohydrates & 0.52 & 0.41 & 0.37 & 0.26 & 27.46 & $\hat{Y}=0.519-0.013 X$ & 0.962 \\
\hline Neutral detergent fibre & 0.57 & 0.55 & 0.66 & 0.64 & 15.38 & $\hat{Y}=0.562+0.005 X$ & 0.55 \\
\hline Lignin & 0.09 & 0.09 & 0.11 & 0.11 & 17.49 & $\hat{Y}=0.092+0.01 X$ & 0.66 \\
\hline Crude protein & 0.15 & 0.13 & 0.15 & 0.13 & 14.04 & $\hat{Y}=0.145$ & - \\
\hline Ether extract & 0.02 & 0.03 & 0.03 & 0.04 & 0.03 & $\hat{Y}=0.028+0.489 X$ & 0.87 \\
\hline TDN & 0.86 & 0.76 & 0.85 & 0.72 & 14.61 & $\hat{Y}=0.802$ & - \\
\hline Weight gain & 0.17 & 0.15 & 0.17 & 0.17 & 18.20 & $\hat{Y}=0.170$ & - \\
\hline
\end{tabular}


The feed: gain ratio for DM, CP and TDN were similar $(p>0.05)$ among treatments. The feed:gain ratio for dietary NSC decreased and NDF increased with the addition of palm kernel in the diet. The feed: gain ratio of NSC improved, and although the consumption of NSC decreased. Weight gain following the addition of palm kernel cake to the diet was similar in all treatments ( $p>0.05$, Table 4$)$.

Table 4. Feed:gain ratio of lambs fed diets containing different levels of palm kernel cake.

\begin{tabular}{|c|c|c|c|c|c|c|c|}
\hline \multirow{2}{*}{ Feed } & \multicolumn{4}{|c|}{$\begin{array}{c}\text { Level of palm kernel } \\
\text { cake }\end{array}$} & \multirow{2}{*}{$\begin{array}{l}\text { CV } \\
(\%)\end{array}$} & \multirow{2}{*}{$\begin{array}{l}\text { Regression } \\
\text { equation }\end{array}$} & \multirow[t]{2}{*}{$\mathbf{R}^{2}$} \\
\hline & 0.00 & 6.50 & 13.00 & 19.50 & & & \\
\hline DM & 7.74 & 7.41 & 7.44 & 6.78 & 16.18 & $\hat{Y}=7.340$ & - \\
\hline $\mathrm{CP}$ & 0.89 & 0.79 & 0.81 & 0.75 & 17.20 & $\hat{\mathrm{Y}}=0.809$ & - \\
\hline TDN & 5.01 & 4.83 & 4.94 & 4.36 & 16.36 & $\hat{Y}=4.785$ & \\
\hline NC & 3.05 & 2.59 & 2.18 & 1.59 & 29.11 & $\hat{Y}=3.069-0.074 X$ & 0.99 \\
\hline NDF & 3.33 & 3.46 & 3.84 & 3.88 & 16.12 & $\hat{Y}=3.325+0.031 X$ & 0.90 \\
\hline
\end{tabular}

$\mathrm{DM}=$ Dry matter; $\mathrm{CP}=$ Crude protein; $\mathrm{TDN}=$ Total digestible nutrient; $\mathrm{NC}=\mathrm{Non}$ structural carbohydrates; NDF=Neutral detergent fibre.

While, morphometric measures were not influenced by the addition of palm kernel cake, the carcass compactness index decreased (Table 5).

The inclusion of palm kernel cake in the diet of lambs reduced the cold carcass weight and commercial yield of the carcass but had no effect on slaughter weight, empty body weight. Yield of refrigeration, weight of the leg and shoulder decreased with the inclusion of palm kernel cake in the diets (Table 6).
Table 6. Carcass characteristics of lambs fed diets containing different levels of palm kernel cake.

\begin{tabular}{|c|c|c|c|c|c|c|}
\hline \multirow{2}{*}{ Characteristic } & \multicolumn{3}{|c|}{ Level of palm kernel } & \multirow{2}{*}{$\begin{array}{l}\text { cake } \\
19.50\end{array}$} & \multirow{2}{*}{$\begin{array}{l}\text { CV } \\
(\%)\end{array}$} & \multirow{2}{*}{$\begin{array}{c}\text { Regression } \\
\text { equation }\end{array}$} \\
\hline & 0.00 & 6.50 & 13.00 & & & \\
\hline \multicolumn{7}{|l|}{ Weight (kg) } \\
\hline Slaughter & 37.51 & 35.93 & 37.48 & 35.53 & 11.01 & $\hat{Y}=36.60$ \\
\hline Empty body & 31.04 & 31.17 & 30.57 & 30.53 & 13.08 & $\hat{Y}=30.82$ \\
\hline Hot carcass ${ }^{1}$ & 16.95 & 15.21 & 16.23 & 14.43 & 8.81 & $\hat{Y}=16.68-0.10 X$ \\
\hline Half carcass & 7.79 & 6.85 & 7.45 & 6.60 & 13.39 & $\hat{\mathrm{Y}}=7.17$ \\
\hline \multicolumn{7}{|c|}{ Yield carcass ( $\%)$} \\
\hline Commercial $^{2}$ & 45.49 & 42.80 & 43.78 & 40.72 & 5.86 & $\hat{Y}=45.20-0.205 X$ \\
\hline $\begin{array}{l}\text { Under } \\
\text { refrigeration }\end{array}$ & 48.15 & 52.70 & 48.34 & 50.65 & 6.34 & $\hat{Y}=49.95$ \\
\hline
\end{tabular}

There was no effect observed for the cuts expressed as percentages (Table 7).

Table 7. Commercial cuts of lambs fed diets containing different levels of palm kernel cake.

\begin{tabular}{|c|c|c|c|c|c|c|}
\hline \multirow{2}{*}{$\begin{array}{l}\text { Commercial } \\
\text { cuts }\end{array}$} & \multicolumn{3}{|c|}{ Level of palm kernel } & \multirow{2}{*}{$\begin{array}{l}\text { cake } \\
19.50\end{array}$} & \multirow{2}{*}{$\begin{array}{l}\text { CV } \\
(\%)\end{array}$} & \multirow{2}{*}{$\begin{array}{c}\text { Regression } \\
\text { equation }\end{array}$} \\
\hline & 0.00 & 6.50 & 13.00 & & & \\
\hline $\begin{array}{l}\text { Weight of half } \\
\text { carcass }\end{array}$ & 7.79 & 6.85 & 7.45 & 6.60 & 13.39 & $\hat{Y}=7.17$ \\
\hline $\begin{array}{l}\text { Shoulder } \\
(\mathrm{kg})^{1}\end{array}$ & 1.69 & 1.52 & 1.63 & 1.45 & 12.07 & $\begin{array}{c}\hat{Y}=1.666- \\
0.0087 X\end{array}$ \\
\hline $\operatorname{Leg}(\mathrm{kg})^{2}$ & 2.59 & 2.40 & 2.46 & 2.21 & 11.40 & $\begin{array}{c}\hat{Y}=2.556- \\
0.16 X\end{array}$ \\
\hline Loin $(\mathrm{kg})$ & 0.31 & 0.27 & 0.30 & 0.25 & 17.76 & $\hat{\mathrm{Y}}=0.280$ \\
\hline Ribs (kg) & 2.01 & 1.63 & 1.87 & 1.66 & 19.98 & $\hat{Y}=1.792$ \\
\hline Neck (kg) & 1.19 & 1.08 & 1.19 & 1.04 & 16.65 & $\hat{Y}=1.127$ \\
\hline Loin $(\%)$ & 2.92 & 3.87 & 4.07 & 3.73 & 11.07 & $\hat{Y}=3.90$ \\
\hline Leg (\%) & 33.30 & 34.39 & 33.14 & 33.58 & 4.95 & $\hat{Y}=33.60$ \\
\hline Ribs (\%) & 25.64 & 23.68 & 25.01 & 24.91 & 9.71 & $\hat{Y}=24.81$ \\
\hline Shoulder (\%) & 21.77 & 22.22 & 21.90 & 22.09 & 4.33 & $\hat{Y}=21.99$ \\
\hline Neck (\%) & 15.37 & 15.83 & 15.89 & 15.69 & 9.96 & $\hat{\mathrm{Y}}=15.70$ \\
\hline
\end{tabular}

$1 \mathrm{R}^{2}=0.854 ;{ }^{2} \mathrm{R}^{2}=0.673$

Table 5. Morphometric measures and carcass index of lambs fed diets containing different levels of palm kernel cake.

\begin{tabular}{|c|c|c|c|c|c|c|c|}
\hline \multirow[b]{2}{*}{ Variable } & \multicolumn{4}{|c|}{ Level of palm kernel cake (\%DM) } & \multirow[b]{2}{*}{ CV(\%) } & \multirow[b]{2}{*}{ Regression equation } & \multirow[b]{2}{*}{$\mathbf{R}^{2}$} \\
\hline & 0.00 & 6.50 & 13.00 & 19.50 & & & \\
\hline Carcass internal length $\mathbf{1}$ & 58.75 & 57.25 & 57.63 & 57.00 & 4.20 & $\hat{Y}=57.66$ & \\
\hline Carcass outer length $\mathbf{1}$ & 55.00 & 54.24 & 54.38 & 53.88 & 5.09 & $\hat{Y}=54.38$ & \\
\hline Leg length $\mathbf{1}$ & 45.13 & 44.38 & 44.13 & 44.25 & 6.36 & $\hat{Y}=44.47$ & \\
\hline Leg perimeter $\mathbf{1}$ & 34.50 & 32.25 & 32.00 & 32.50 & 7.03 & $\hat{Y}=32.81$ & \\
\hline Hind width 1 & 42.50 & 41.00 & 41.75 & 40.25 & 4.15 & $\hat{Y}=41.38$ & \\
\hline Hind perimeter $\mathbf{1}$ & 65.63 & 63.88 & 66.25 & 63.13 & 3.93 & $\hat{Y}=64.72$ & \\
\hline Thoracic perimeter $\mathbf{1}$ & 72.75 & 71.38 & 72.38 & 71.50 & 4.85 & $\hat{Y}=72.00$ & \\
\hline Carcass compactness index (\%) & 0.31 & 0.28 & 0.30 & 0.27 & 8.81 & $\hat{Y}=0.307-0.002 X$ & 0.56 \\
\hline Leg muscularity & 0.49 & 0.48 & 0.50 & 0.51 & 8.81 & $\hat{Y}=0.50$ & - \\
\hline Rib eye area $\left(\mathrm{cm}^{2}\right)$ & 8.49 & 7.76 & 8.64 & 7.30 & 19.70 & $\hat{Y}=8.05$ & - \\
\hline
\end{tabular}




\section{DISCUSSION}

As shown in tables 2 and 3, the NDF content in diets and lignin intake increased with increasing levels of palm kernel cake, which may have caused the accompanying decrease in DM intake, since lignin is less digestible than others cellular walls components and prevents the digestion of other components of the cell wall by its recalcitrant effect. Earlier studies (23) observed a linear decrease in DM intake in sheep fed up to $29.7 \%$ of palm kernel cake in place of wheat bran. Silva et al (24) reported a reduction in total DM intake in calves aged 60 to 120 days with the addition of palm kernel cake into daily concentrate, and attributed this reduction to the high fiber content in the palm kernel cake.

The consumption of NDF increased $(p<0.05)$ as the proportion of palm kernel cake increased in the diet. This might be a response to the high levels of NDF in the palm kernel cake (Table 1) which also resulted in an increase in NDF content in the experimental diets (Table 2). Despite the decrease in DM intake, the increasing quantities of NDF content in the diets might be responsible for those results. Silva et al (25) found that diets containing ammonized elephant grass and palm kernel cake for sheep increase in NDF intake in a group fed with $40 \%$ palm kernel. The results were consistent with our findings, and were attributed to the levels of NDF in the product.

The consumption of non-structural carbohydrates decreased $(p<0.05)$ with the addition of palm kernel cake in the diet (Table 3 ). This may have been due to the reduction of these components in the diet and the decrease in dry matter intake (Table 2). Castro et al (26), observed a linear decrease in NSC intake in Santa Inês lambs using diets containing maniçoba (Manihotglaziovii) hay, this was attributed to the decrease in NSC in diets following the addition of maniçoba hay. Despite the reduction in dry matter intake, the different palm kernel cake levels had no effect on the consumption of CP (Table 3), the decrease in the dry matter consumption could also reduce the consumption of $\mathrm{CP}$, which was partly offset by the content of CP of the palm kernel. Consumption of palm kernel also contributed to the increase in the EE. Weight gain following the addition of palm kernel cake to the diet was similar in all treatments $(p>0.05)$, which might be a consequence of TDN intake, because energy is the most important fraction for weight gain, increasing the energy content of a diet does not necessarily mean higher energy intake for the animal to the addition of TDN. Dietary differences in characteristics provided this increase should be accompanied by greater intake of the TDN that was not found in this experiment. Although there were differences of some the carcass characteristics, Carvalho et al (27), they observed that the inclusion of cocoa meal in feed for sheep, have a similar response (daily weight gain $0.140 \mathrm{~kg} /$ day).

The feed:gain ratio of NSC improved, and although the consumption of NSC decreased, there was probably better use of the nutrients, because the NSC was replaced by EE from the palm kernel cake, leading to the consumption and conversion of TDN to similar treatments. The conversion of NDF decreased with the addition of palm kernel cake and the consumption of NDF probably increased to maintain the same body weight gain. The morphometric measures, (Table 5 ) have not been influenced by the addition of palm kernel cake, probably due to the low consume of DM and digestibility of NSC, which have reflected in the similarities between the treatments for energy and protein consume.

The carcass weights and proportions of commercial cuts did not differ between treatments (Table 7), probably because the treatment did not affect body weight at slaughter. This is related to anatomical harmony cited by Boccard and Dummond (28), according to which, carcass weights and similar amounts of fat, all regions are in similar proportions

The carcass compactness index, have shown decreased linear behavior with addition of palm kernel cake, probably due to the increase of the NDF content 
plus the higher lignin and lower DM intake could have contributed to the reduction in carcass weight.

The increase in NDF content plus the higher lignin and lower DM intake could have contributed to the reduction in carcass weight. Studies on Santa Ines Sheep carcass characteristics, grazed on natural pasture and submitted to levels of supplementation, reported differences on the carcass compactness, related to the variation on carcass weight, since the body measures did not have influence of supplementation level ( 29).

This could be attributed to the increasing NDF and decreasing NSC intake (Table 3), which in turn might have resulted in the lower deposition of muscle mass in the carcass as a consequence of reduced nutrient levels (30).

On the other hand, body weight at slaughter was similar for all treatments, although as the shoulder and leg are composed of muscles in early development their proportions may decrease as the animal grows. The leg muscle and leg compactness indexes were not influenced by the addition of palm kernel cake, probably due to the similarities in the consumption of protein and energy, which resulted in similar weight gain and slaughter weight among treatments.

The rib eye area is an important variable for predicting the amount of carcass muscle, but must be considered with other carcass characteristics to better evaluate the composition of the carcass (31).

The values observed in this study are similar to those reported by Cunha et al (32), who studied the quantitative characteristics of Santa Inês lambs fed with different levels of whole cotton seed reported values of 31.63 and $21.99 \%$ for leg and shoulder, respectively.

We conclude that the addition of up to $19.5 \%$ palm kernel cake reduces DM intake, the carcass compactness index and the commercial yield, but has no effect on weight gain, refrigeration yield or feed dry matter.

\section{REFERENCES}

1. Siqueira $E R$, Simões $C D$, Fernandes S. Effect of sex and slaughter weight on production of beef and lamb. Morphometry of the carcass, cuts weights, tissue composition and not constituent component of the carcass. $\mathrm{R}$ Bras Zootec 2001; 30(4):1299-1307.

2. Brazilian Institute of Geography and Statistics - IBGE. Search local livestock. [Accessed on: 20 April 2006]. URL Available at: www.ibge.gov.br.

3. Cezar MF. Carcass characteristics and physiological adaptability of sheep during the create. [Doctoral Thesis]. Brazil, Areia: Universidade Federal da Paraiba. Faculty of Zootecnia, Animal Production Department; 2004.
4. Furusho Garcia IF, Olalquiaga Perez JR, Teixeira JC. Carcass components and composition of some cuts of lamb Texel x Bergamacia, Texel x Santa Inês Santa Inês and finished in pure containment shell of coffee as part of the diet. R Bras Zootec 2003; 32(6):1999-2006.

5. Osório JCS. Study of carcass quality commercialized in the type depending on the origin: basis for the improvement of quality of carcasses in Brazil. [Doctoral Thesis]. España: University of Zaragoza; 1992.

6. Correia $B R$, Oliveira $\mathrm{RL}$, Jaeger $\mathrm{SMPL}$, Bagaldo AR, Carvalho GGP, Oliveira GJC, Lima FHS, Oliveira PA. Intake, digestibility and ruminal $\mathrm{pH}$ of steers fed diets with pies coming from the production from biodiesel to replacement soybean meal. Arq Bras Med Vet 2011; 63: 353-363. 
7. Borja MS, Oliveira RL, Ribeiro CVDM, Bagaldo AR, Carvalho GGP, Silva TM, Lima LS, Barbosa LP. Effects of feeding licury (Syagrus coronate) cake to growing goats. Asian-australas ] Anim Sci 2010; 23: 1436-1444.

8. Nunes AS, Oliveira RL, Ayres MCC, Bagaldo AR, Garcez Neto A F, Barbosa LP. Hepatic condition of lambs fed diets with palm kernel cake from biodiesel production. R Bras Zootec 2010; 39: 1825-1831.

9. Dias $A M A$, Batista $A M V$, Maia MMD, Carvalho FFR, Guim A, Silva G, Silva AC. Nutrient intake and digestibility and performance of goats fed rough wheat bran in place of corn. R Bras Zootec 2010; 39:831-836.

10. Brazilian Ministry of Agriculture. Brazilian: Compendium of animal nutrition; 1998.

11. Ribeiro RDX, Oliveira RL, Macome FM, Bagaldo AR, Silva MCA, Ribeiro CVDM, et al. Meat quality of lambs fed on palm kernel meal, a by-product of biodiesel production. Asian-australas J Anim Sci 2011; 24:1399-1406.

12. Association of Analytical Chemists. AOAC. Official methods of analysis. 12th ed. Washington: AOAC; 1990.

13. Van Soest, PJ, Robertson JB, Lewis BA. Methods for dietary fiber, neutral detergent fiber, and nonstarch polysaccharides in relation to animal nutrition. J Dairy Sci 1991; 74(10):3583-3597.

14. Sniffen CJ, O'Conor JD, Van Soest PJ, Fox DG, Russel JB. A net carbohydrate and protein system for evaluating cattle diets: Carbohydrate and protein availability. J Anim Sci 1992; 70(11):3562-3577.

15. Yanez EA, Resende $\mathrm{KJ}$, Ferreira $A C D$, Medeiros AN, Sobrinho Silva AG, Pereira Filho JM et al. Use of biometric measures to predict characteristics of Saanen goats. R Bras Zootec 2004; 33(6):1565-1572.
16. Colomer-Rocher $F$, Morand-Feher $P$, Kirton AH. Standard methods and procedures for goat carcass evaluation, jointing and tissue separation. Livest Prod Sci 1987; 17:149-159.

17. Osorio JC, Osorio MT, Jardim PO, Pimentel M, Pouey JL, Luder WE et al. Methods to evaluate the production of lamb in vivo, the carcass and meat. Pelotas: UFPEL; 1998.

18. Garcia CA, Sobrinho Silva AG. Performance and carcass characteristics of sheep fed with residue of bread "cookie". In: Annual Meeting of the Bras. Society Zooctec 1998; 29-31.

19. Silva Sobrinho AG, Machado MRF, Gastaldi KA et al. Effect of forage:concentrate ratio and slaughter weight on the leg components of lambs Ile de France $x$ Texel confined. J Anim Sci 2002; 31:1017-1023.

20. Silva Sobrinho AG, Purchas RW, Kadim IT, Yamamoto SM. Composition of the leg muscle of sheep of different genotypes and ages at slaughter. Pesqui Agropecu Bras 2005; 40(11):1129-1134.

21. Purchas RW, Davies AS, Abdullah AY. An objective measure of muscularity: changes with animal growth and differences between genetic lines of Southdown sheep. Meat Sci 1991; 30:81-94.

22. Statistical Package for the Social Sciences - SPSS. Release 13.0. Chicago, 2004.

23. Rodrigues Filho JA, Shrimp AP, Batista $H$, Azevedo GPC, Braga E. Levels of cake to replace the palm of wheat bran on voluntary intake and digestibility of concentrates. R Bras Zootec 1996; 292-293.

24. Silva FF, Pires AJV, Oliveira ARA, et al. Cake of palm in diets of dairy calves weaned early. In: 37th annual meeting of Brazilian Society of Zootecnia, Viçosa, MG. Viçosa, MG; 2000. 
25. Silva HGO, Pires AJV, Carvalho GGP, Veloso CM, Silva FF. Consumption of diets containing corn silage of elephant grass and amonizado cocoa meal or palm cake by sheep. R Bras Zootec 2008; 37(4):734-742.

26. Castro JMC, Silva DS, Medeiros AN, Pimenta Filho EC. Performance of Santa Ines lambs fed diets containing full of hay Maniçoba. R Bras Zootec 2007; 6(3):674-680.

27. Carvalho GP, Pires AJV, Veloso CM, Silva FF, Silva RR. Performance and digestibility in sheep fed meal from cocoa (Theobroma cacao L.) at different levels of substitution. $\mathrm{R}$ Bras Zootec 2006; 7(2):115-122.

28. Boccard R, Drumound BL. Etude de la production de la viande chez le ovins and variation de I importance relative de different regions corporelles de $I^{\prime}$ agneaus de boucgerie. Ann Zootec 1960; 9:355-365.

29. Dantas $A F$, Pereira Filho JM, Silva Azevedo AM, Santos EM, Sousa BB, Cezar MFA. Carcass characteristics of Santa Ines sheep completed in grazing and submitted to different levels of supplementation. Agrotec Sci 2008; 32(4):1280-1286.
30. Silva $T M$, Oliveira $R L$, Barbosa $L P$, Garcez Neto AF, Bagaldo AR, Lanna DPD, Silva MCA, Jesus IB. Preliminary study on meat quality of goats fed levels of licury oil in the diet. Asian-australas J Anim Sci 2011; 24:1112-1119.

31. Louvandini $H$, Nunes GA, Soares Garcia JA, Mcmanus C, Costa DM, Araujo SC. Performance, carcass characteristics and body constituents of Santa Inês sheep fed sunflower meal in place of soybean meal in diet. R Bras Zootec 2007; 36(3): 603-609.

32. Cunha MGG, Carvalho FFR, Gonzaga Neto S, Cezar MF. Quantitative carcass characteristics of Santa Inês sheep feedlot fed diets containing different levels of whole cottonseed. $\mathrm{R}$ Bras Zootec 2008; 37(6): 1112-1120. 